\title{
Microterricola viridarii gen. nov., sp. nov., a new member of the family Microbacteriaceae
}

Correspondence

Yōko Takahashi

ytakaha@lisci.kitasato-u.ac.jp

\author{
Atsuko Matsumoto, ${ }^{1}$ Mayuko Yamada, ${ }^{2}$ Satoshi Ōmura ${ }^{1,2}$ \\ and Yōko Takahashi ${ }^{2}$ \\ ${ }^{1}$ The Kitasato Institute, 5-9-1 Shirokane, Minato-ku, Tokyo 108-8642, Japan \\ ${ }^{2}$ Kitasato Institute for Life Sciences, Kitasato University, 5-9-1 Shirokane, Minato-ku, \\ Tokyo 108-8641, Japan
}

\begin{abstract}
Strain $\mathrm{KV}-677^{\top}$, a Gram-positive, aerobic, motile, rod-shaped bacterium, was isolated from park soil in Tokyo, Japan, and characterized. It grew well at $15-30{ }^{\circ} \mathrm{C}$ on nutrient agar and colonies were pale yellow. The cell-wall peptidoglycan contained diaminobutyric acid, glycine, alanine and glutamic acid and the muramic acid acyl type was acetyl. The predominant menaquinone was MK-12. Mycolic acids were not detected. The DNA G + C content was 70 mol\%. 16S rRNA gene sequence analysis revealed that strain $\mathrm{KV}-677^{\top}$ fell within the cluster of the family Microbacteriaceae and formed a separate lineage joining the genera Salinibacterium, Rhodoglobus, Subtercola and Agreia, showing 95.5-96.9\% sequence similarities with the type strains of the type species of the above genera. However, strain $\mathrm{KV}-677^{\top}$ clearly differed from these and other genera with relatively high sequence similarity in its chemotaxonomic characteristics. Therefore, it is proposed that strain $\mathrm{KV}-677^{\top}$ represents a novel species in a new genus, Microterricola viridarii gen. nov., sp. nov., in the family Microbacteriaceae. The type strain of Microterricola viridarii is $\mathrm{KV}-677^{\top}$ (=NRRL B-24538 ${ }^{\top}=$ NBRC $102123^{\top}$ ).
\end{abstract}

A novel strain, $\mathrm{KV}-677^{\mathrm{T}}$, was isolated from park soil in Tokyo. The strain contained diaminobutyric acid (DAB) as the diamino acid in the cell wall and other chemotaxonomic characteristics and phylogenetic analysis showed that the strain belonged to the family Microbacteriaceae (Park et al., 1993; Stackebrandt et al., 1997). Currently, the family Microbacteriaceae consists of 21 genera, including Agreia (Evtushenko et al., 2001), Agrococcus (Groth et al., 1996), Agromyces (Gledhill \& Casida, 1969; Zgurskaya et al., 1992), Clavibacter (Davis et al., 1984), Cryobacterium (Suzuki et al., 1997), Curtobacterium (Yamada \& Komagata, 1972), Frigoribacterium (Kämpfer et al., 2000), Gulosibacter (Manaia et al., 2004), Leifsonia (Evtushenko et al., 2000), Leucobacter (Takeuchi et al., 1996), Microbacterium (Takeuchi \& Hatano, 1998), Microcella (Tiago et al., 2005), Mycetocola (Tsukamoto et al., 2001), Okibacterium (Evtushenko et al., 2002), Plantibacter (Behrendt et al., 2002), Pseudoclavibacter (Manaia et al., 2004), Rathayibacter (Zgurskaya et al., 1993), Rhodoglobus (Sheridan et al., 2003), Salinibacterium (Han et al., 2003),

Abbreviations: DAB, diaminobutyric acid; SEM, scanning electron microscopy; TEM, transmission electron microscopy.

The GenBank/EMBL/DDBJ accession number for the 16S rRNA gene sequence of strain $\mathrm{KV}-677^{\top}$ is $\mathrm{AB} 282862$.

Scanning electron micrographs of cells of $\mathrm{KV}-677^{\top}$ cultured on nutrient agar at $27{ }^{\circ} \mathrm{C}$ for $8 \mathrm{~h}$ and for 10 days are available as supplementary material with the online version of this paper.
Subtercola (Männistö et al., 2000) and Yonghaparkia (Yoon et al., 2006); Zimmermannella (Lin et al., 2004) is a homotypic synonym of Pseudoclavibacter. At the time of writing, Labedella (Lee, 2007) was also added. In this study, a novel species in a new genus of the family Microbacteriaceae is described.

Strain $\mathrm{KV}-677^{\mathrm{T}}$ was isolated using GPM agar $(1 \%$ Dglucose, $0.5 \%$ peptone, $0.5 \%$ meat extract, $0.3 \% \mathrm{NaCl}$, $1.2 \%$ agar, pH 7) containing $0.002 \%$ Benlate (Dupont) and $0.0025 \%$ nalidixic acid (Sigma) from soil collected at Arisugawa Park in the Tokyo metropolitan area, Japan, after incubation for 1 week at $27{ }^{\circ} \mathrm{C}$. Morphological characteristics of the strain were observed by scanning electron microscopy (SEM) (JSM-5600; JEOL) and transmission electron microscopy (TEM) (JEM-1200EXII; JEOL). For SEM, cells grown in TSB (Difco) for 3 days at $27{ }^{\circ} \mathrm{C}$ were rinsed with $0.05 \mathrm{M}$ Tris/ $\mathrm{HCl}$ buffer $(\mathrm{pH}$ 7.6) and filtered onto a membrane. The sample was fixed using $4 \%$ osmium tetroxide vapour following lyophilization with liquid nitrogen. For TEM, cells grown on nutrient agar for 2 days at $27{ }^{\circ} \mathrm{C}$ were stained with $1.5 \%$ (w/v) uranyl acetate after cell motility was observed with a light microscope. Gram-staining was performed using a Gram's stain reagent kit (Nacalai Tesque). Cultural and physiological characteristics were observed after incubation for 2 days at $27{ }^{\circ} \mathrm{C}$. The $\mathrm{NaCl}$ tolerance and $\mathrm{pH}$ range for growth were determined on YD agar $(1.0 \%$ yeast extract, 
$1.0 \%$ glucose, $1.2 \%$ agar, $\mathrm{pH} 7.0$ ) and the temperature range for growth was examined on nutrient agar (Difco) between 5 and $50{ }^{\circ} \mathrm{C}$ using a gradient incubator. Resistance to antibiotics was tested on nutrient agar using antibiotic discs (KB discs; Eiken Chemical). Carbon source utilization was determined using API $50 \mathrm{CH}$ test strips (bioMérieux) and general biochemical characteristics were determined using API ZYM test strips (bioMérieux) according to the manufacturer's instructions.

The muramic acid acyl type was determined by the method of Uchida \& Aida (1977). Purified cell wall was obtained using the method of Kawamoto et al. (1981) and $1 \mathrm{mg}$ purified cell wall preparation was hydrolysed at $100{ }^{\circ} \mathrm{C}$ with $1 \mathrm{ml} 6 \mathrm{M} \mathrm{HCl}$ for $15 \mathrm{~h}$. The hydrolysate was dissolved in $100 \mu \mathrm{l}$ water and used for amino acid analysis. Amino acid composition was determined by HPLC using the PicoTag method (Waters). The presence of mycolic acids was examined by TLC according to Tomiyasu (1982) and phospholipids were extracted and identified following the method of Minnikin et al. (1977). Menaquinones were extracted and purified by the method of Collins et al. (1977) and then analysed by HPLC (model 802-SC; Jasco) equipped with a CAPCELL PAK C18 column (Shiseido) (Tamaoka et al., 1983). Analysis of fatty acids in cells grown on TSA (Becton Dickinson) at $28{ }^{\circ} \mathrm{C}$ for $52 \mathrm{~h}$ was performed according to the procedures of the Sherlock microbial identification system (Microbial ID).

DNA was isolated as described by Saito \& Miura (1963). DNA base composition was estimated by the HPLC method of Tamaoka \& Komagata (1984).

DNA for analysis of the 16S rRNA gene sequence was prepared by the method of Yu et al. (2002). The 16S rRNA gene was amplified by PCR using previously described methods (Takahashi et al., 2002) and was sequenced directly on an ABI model 3130 automatic DNA sequencer using a BigDye terminator cycle sequencing kit (Applied Biosystems). The CLUSTAL w software (Thompson et al., 1994) was used for multiple alignment with selected sequences and for calculating evolutionary distances (Kimura, 1980) and the phylogenetic tree was constructed by the neighbour-joining method (Saitou \& Nei, 1987). Data were resampled with 1000 bootstrap replications (Felsenstein, 1985). The PHYLIP software (Felsenstein, 1981) was used to create a phylogenetic tree by the maximumlikelihood method. Sequence similarity values were determined by visual comparison and manual calculation.

Strain $\mathrm{KV}-677^{\mathrm{T}}$ grew well on nutrient agar and colonies were pale yellow. The strain was Gram-positive. Cells were irregular rods $(0.4-0.5 \times 0.6-1.2 \mu \mathrm{m})$ in TSB (Fig. 1a) and were longer in early cultures on nutrient agar (see Supplementary Fig. S1 in IJSEM Online). Cell motility was observed and TEM observation showed that cells had long flagella (Fig. 1b). Strain $\mathrm{KV}-677^{\mathrm{T}}$ grew at $10-38^{\circ} \mathrm{C}$, with optimum growth at $15-30{ }^{\circ} \mathrm{C}$. Growth was observed at initial pH 6-11. The strain did not grow in the presence
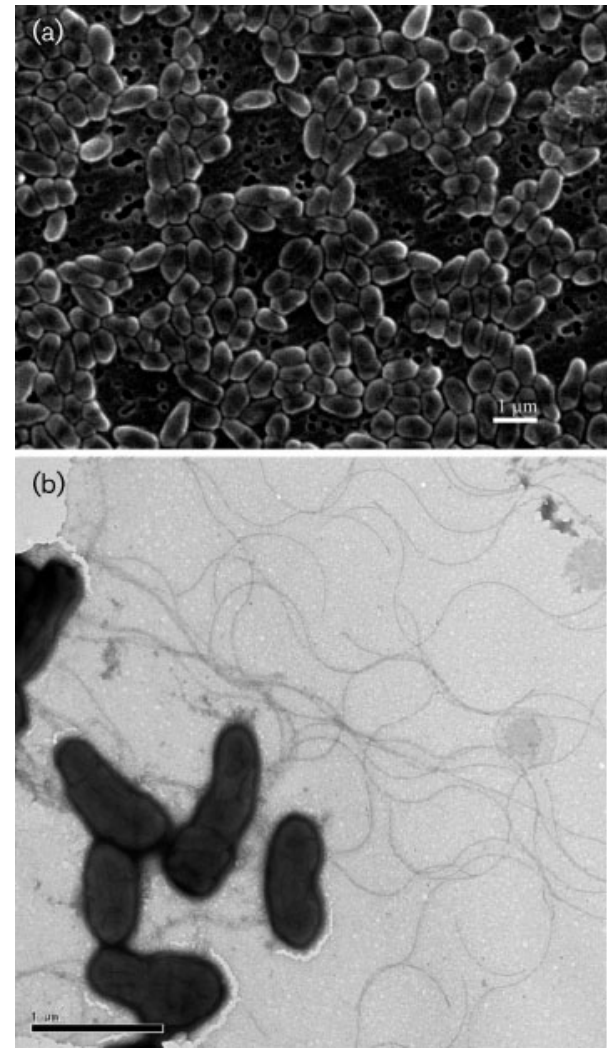

Fig. 1. Electron micrographs of strain $\mathrm{KV}-677^{\top}$. (a) SEM of cells cultured in TSB for 3 days at $27^{\circ} \mathrm{C}$. (b) TEM of cells cultured on nutrient agar for 2 days at $27^{\circ} \mathrm{C}$.

of $4 \% \mathrm{NaCl}$ and was resistant to nalidixic acid $(30 \mu \mathrm{g})$, aztreonam $(30 \mu \mathrm{g})$ and oxacillin $(1 \mu \mathrm{g})$.

The cell-wall peptidoglycan contained DAB, glycine, alanine and glutamic acid. The muramic acid acyl type was acetyl. The predominant menaquinone was MK-12 (69\%); MK-11 (21\%) and MK-13 (10\%) were minor menaquinones (Table 1). For unknown reasons, the amount of menaquinones in this strain was found to be significantly smaller than in members of the family Microbacteriaceae analysed previously. Mycolic acids were not detected. The dominant cellular fatty acid components were 12-methyltetradecanoic (anteiso-15:0, 63\%), 14methylhexadecanoic (anteiso-17:0, 21\%), 14-methylpentadecanoic (iso-16:0, 9\%), 13-methyltetradecanoic (iso$15: 0,3 \%)$ and $n$-hexadecanoic $(16: 0,3 \%)$ acids. The DNA G + C content was 70 mol\%. An almost complete $16 \mathrm{~S}$ rRNA gene sequence (1442 bp) was determined for strain $\mathrm{KV}-677^{\mathrm{T}}$. The phylogenetic tree revealed that strain $\mathrm{KV}-$ $677^{\mathrm{T}}$ forms a separate lineage within the clade of the family Microbacteriaceae, joining the genera Salinibacterium, Rhodoglobus, Subtercola and Agreia (Fig. 2). Sequence similarities between strain $\mathrm{KV}-677^{\mathrm{T}}$ and the type strains of the type species of the above genera were 96.5, 95.5, 96.0 and $96.9 \%$, respectively. Strain $\mathrm{KV}-677^{\mathrm{T}}$ clearly differed 
Table 1. Characteristics of genera in the family Microbacteriaceae

Data for reference genera are from the descriptions of genera from the following references: Behrendt et al. (2002), Davis et al. (1984), Evtushenko et al. (2000, 2001, 2002), Han et al. (2003), Groth et al. (1996), Kämpfer et al. (2000), Manaia et al. (2004), Männistö et al. (2000), Sasaki et al. (1998), Schumann et al. (2003), Suzuki et al. (1997, 1999), Takeuchi et al. (1996), Takeuchi \& Hatano (1998), Tiago et al. (2005), Tsukamoto et al. (2001), Wieser et al. (1999), Yoon et al. (2006) and Zgurskaya et al. (1993). ND, No data available.

\begin{tabular}{|c|c|c|c|c|}
\hline Genus & Motility & $\begin{array}{c}\text { Diamino } \\
\operatorname{acid}(s)^{\star}\end{array}$ & $\begin{array}{l}\text { Acyl } \\
\text { type }\end{array}$ & $\begin{array}{c}\text { Major } \\
\text { menaquinone(s) }\end{array}$ \\
\hline Microterricola & + & DAB & Acetyl & 12 \\
\hline Agreia &,+- & DAB, Orn & Acetyl & 10 \\
\hline Agrococcus & - & $\mathrm{DAB}$ & Acetyl & 11,12 \\
\hline Agromyces & - & $\mathrm{DAB}$ & Acetyl & 12 \\
\hline Clavibacter & - & $\mathrm{DAB}$ & Acetyl & 9 \\
\hline Cryobacterium & - & $\mathrm{DAB}$ & Acetyl & 10 \\
\hline Curtobacterium &,+- & Orn & Acetyl & 9 \\
\hline Frigoribacterium & + & Lys & Acetyl & 9 \\
\hline Gulosibacter & - & Orn & $\mathrm{ND}$ & 9 \\
\hline Leifsonia &,+- & $\mathrm{DAB}$ & Acetyl & 11,10 \\
\hline Leucobacter & - & $\mathrm{DAB}$ & Acetyl & 11 \\
\hline Microbacterium &,+- & Lys, Orn & Glycolyl & $11,12,13$ \\
\hline Microcella & - & Lys, Orn & $\mathrm{ND}$ & 12,13 \\
\hline Mycetocola & - & Lys & Acetyl & 10 \\
\hline Okibacterium & - & Lys & Glycolyl & 10,11 \\
\hline Planibacter & - & DAB & Acetyl & 10,11 \\
\hline Pseudoclavibacter & - & $\mathrm{DAB}$ & Acetyl & 9 \\
\hline Rathayibacter & - & $\mathrm{DAB}$ & $\mathrm{ND}$ & 10 \\
\hline Rhodoglobus & + & Orn & $\mathrm{ND}$ & 12,11 \\
\hline Salinibacterium & - & Lys, Orn & Acetyl & 11 \\
\hline Subtercola & - & $\mathrm{DAB}$ & Acetyl & 10,9 \\
\hline Yonghaparkia & - & $\mathrm{DAB}$ & $\mathrm{ND}$ & 12 \\
\hline
\end{tabular}

${ }^{\star}$ DAB, Diaminobutyric acid; Lys, lysine; Orn, ornithine. from the above four genera, as well as from the other genera with high $16 \mathrm{~S}$ rRNA gene sequence similarity (96.5$96.8 \%$ ), Leifsonia, Frigoribacterium and Okibacterium, in the presence of DAB as the sole cell-wall diamino acid and MK-12 as the major menaquinone. Therefore, it is proposed that strain $\mathrm{KV}-677^{\mathrm{T}}$ represents a novel species in a new genus within the family Microbacteriaceae, Microterricola viridarii gen. nov., sp. nov.

\section{Description of Microterricola gen. nov.}

Microterricola (Mic.ro.ter'ri.co.la. Gr. adj. micros small; L. fem. n. terricola dweller in soil; L. fem. n. Microterricola a small dweller in soil).

Cells are Gram-positive, catalase-positive, aerobic and motile. Cells are irregular rods. The cell-wall peptidoglycan contains DAB, glycine, alanine and glutamic acid. The acyl type is acetyl. Predominant menaquinone is MK-12 and minor menaquinones are MK-11 and MK-13. Predominant cellular fatty acids are anteiso-branched (anteiso-15:0, anteiso-17:0). Mycolic acids are not detected. Mesophilic. The type species is Microterricola viridarii.

\section{Description of Microterricola viridarii sp. nov.}

Microterricola viridarii (vi.ri.da'ri.i. L. gen. n. viridarii of a pleasure-garden, the place where the type strain was isolated).

General morphological, chemotaxonomic and growth characteristics are as given above in the genus description. Colonies are pale yellow in colour. Cell size is about 0.4$0.5 \times 0.6-1.2 \mu \mathrm{m}$. The temperature range for growth is $10-$ $38{ }^{\circ} \mathrm{C}$ and the optimum range is $15-30{ }^{\circ} \mathrm{C}$. Growth occurs at initial pH 6-11. Glycerol, L-arabinose, D-ribose, aesculin, maltose and glycogen are utilized as carbon sources, but erythritol, D-arabinose, D- and L-xylose, D-adonitol, methyl $\beta$-D-xylopyranoside, D-galactose, D-glucose, D-fructose,

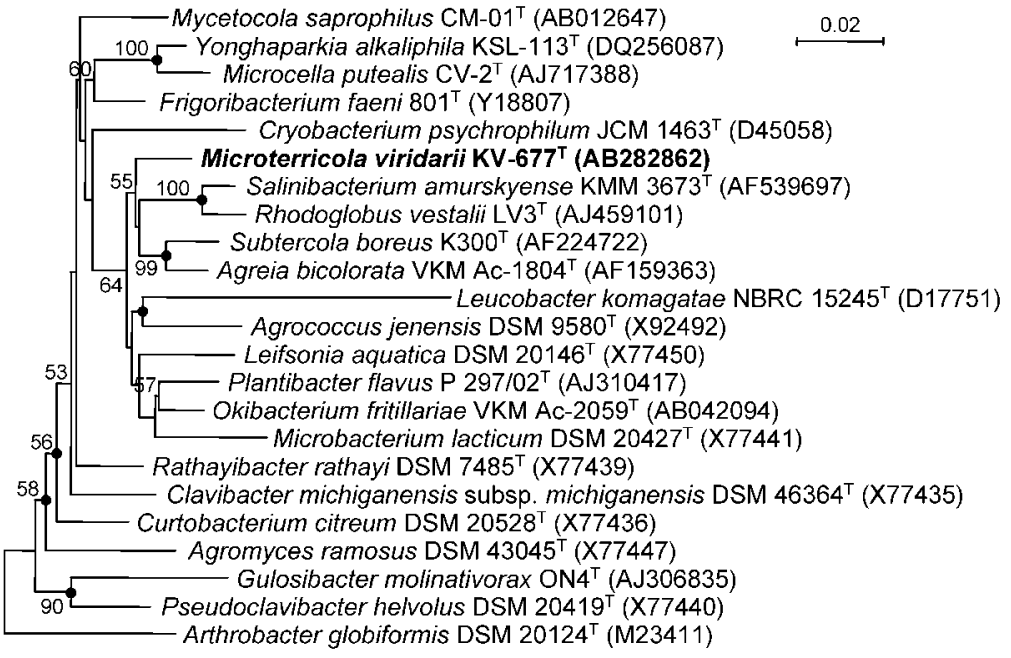

http://ijs.sgmjournals.org
Fig. 2. Phylogenetic tree, derived from $16 \mathrm{~S}$ rRNA gene sequences, created using the neighbour-joining method and $K_{\text {nuc }}$ values. Only bootstrap values above $50 \%$ (percentages of 1000 replications) are indicated. Solid circles indicate that the corresponding nodes are also recovered in the maximum-likelihood tree. Bar, 0.02 substitutions per nucleotide position. 
D-mannose, L-sorbose, L-rhamnose, dulcitol, inositol, Dmannitol, D-sorbitol, methyl $\alpha$-D-mannopyranoside, methyl $\alpha$-D-glucopyranoside, $N$-acetylglucosamide, amygdalin, arbutin, salicin, cellobiose, D-lactose, melibiose, sucrose, trehalose, inulin, melezitose, raffinose, starch, xylitol, gentiobiose, turanose, D-lyxose, D-tagatose, D- and L-fucose, D- and L-arabitol, potassium gluconate, potassium 2-ketogluconate and potassium 5-ketogluconate are not utilized. No growth occurs in the presence of $4 \%(\mathrm{w} / \mathrm{v})$ $\mathrm{NaCl}$. Cells are susceptible to tetracycline $(30 \mu \mathrm{g})$, polymyxin B (300 U), amikacin $(30 \mu \mathrm{g})$, chloramphenicol $(30 \mu \mathrm{g})$, erythromycin $(15 \mu \mathrm{g})$, norfloxacin $(10 \mu \mathrm{g})$, ciprofloxacin $(5 \mu \mathrm{g})$, tobramycin $(10 \mu \mathrm{g})$, vancomycin $(30 \mu \mathrm{g})$, kanamycin $(30 \mu \mathrm{g})$, gentamicin $(10 \mu \mathrm{g})$, ampicillin $(10 \mu \mathrm{g})$, imipenem $(10 \mu \mathrm{g})$ and ceftazidime $(30 \mu \mathrm{g})$. Leucine arylamidase, acid phosphatase, naphthol-AS-BIphosphohydrolase and $\alpha$-glucosidase are present, but alkaline phosphatase, lipase (C8), valine arylamidase, cystine arylamidase, trypsin, chymotrypsin, $\alpha$-galactosidase, $\beta$-galactosidase, $\beta$-glucuronidase, $N$-acetyl- $\beta$-glucosaminidase, $\alpha$-mannosidase and $\alpha$-fucosidase are absent. The predominant cellular fatty acid components are anteiso$15: 0$, anteiso- $17: 0$, iso- $16: 0$, iso- $15: 0$ and $16: 0$. The DNA G $+C$ content of the type strain is $70 \mathrm{~mol} \%$.

The type strain is $\mathrm{KV}-677^{\mathrm{T}}$ (=NRRL B- $24538^{\mathrm{T}}=\mathrm{NBRC}$ $102123^{\mathrm{T}}$ ), isolated from park soil in Tokyo (Japan).

\section{Acknowledgements}

This study was supported in part by a grant of the 21st Century COE Program, Ministry of Education, Culture, Sports, Science and Technology (MEXT), Japan, Grants-in-Aid for Scientific Research of JSPS, the Institute for Fermentation, Osaka (IFO), and a grant for All Kitasato Project Study (AKPS).

\section{References}

Behrendt, U., Ulrich, A., Schumann, P., Naumann, D. \& Suzuki, K. (2002). Diversity of grass-associated Microbacteriaceae isolated from the phyllosphere and litter layer after mulching the sward; polyphasic characterization of Subtercola pratensis sp. nov., Curtobacterium herbarum sp. nov. and Plantibacter flavus gen. nov., sp. nov. Int $J$ Syst Evol Microbiol 52, 1441-1454.

Collins, M. D., Goodfellow, M. \& Minnikin, D. E. (1977). Distribution of menaquinones in actinomycetes and corynebacteria. $J$ Gen Microbiol 100, 221-230.

Davis, M. J., Gillaspsie, A. G., Jr, Vidaver, A. K. \& Harris, R. W. (1984). Clavibacter: a new genus containing some phytopathogenic coryneform bacteria, including Clavibacter xyli subsp. xyli sp. nov., subsp. nov. and Clavibacter xyli subsp. cynodontis subsp. nov., pathogens that cause ratoon stunting disease of sugarcane and Bermudagrass stunting disease. Int J Syst Bacteriol 34, 107-117.

Evtushenko, L. I., Dorofeeva, L. V., Subbotin, S. A., Cole, J. R. \& Tiedje, J. M. (2000). Leifsonia poae gen. nov., sp. nov., isolated from nematode galls on Poa апnua, and reclassification of 'Corynebacterium aquaticum' Leifson 1962 as Leifsonia aquatica (ex Leifson 1962) gen. nov., nom. rev., comb. nov. and Clavibacter xyli Davis et al. 1984 with two subspecies as Leifsonia xyli (Davis et al. 1984) gen. nov., comb. nov. Int J Syst Evol Microbiol 50, 371-380.
Evtushenko, L. I., Dorofeeva, L. V., Dobrovolskaya, T. G., Streshinskaya, G. M., Subbotin, S. A. \& Tiedje, J. M. (2001). Agreia bicolorata gen. nov., sp. nov., to accommodate actinobacteria isolated from narrow reed grass infected by the nematode Heteroanguina graminophila. Int J Syst Evol Microbiol 51, 2073-2079.

Evtushenko, L. I., Dorofeeva, L. V., Krausova, V. I., Gavrish, E. Y., Yashina, S. G. \& Takeuchi, M. (2002). Okibacterium fritillariae gen. nov., sp. nov., a novel genus of the family Microbacteriaceae. Int J Syst Evol Microbiol 52, 987-993.

Felsenstein, J. (1981). Evolutionary trees from DNA sequences: a maximum likelihood approach. J Mol Evol 17, 368-379.

Felsenstein, J. (1985). Confidence limits on phylogenies: an approach using the bootstrap. Evolution 39, 783-791.

Gledhill, W. E. \& Casida, L. E. (1969). Predominant catalase-negative soil bacteria. III. Agromyces, gen. n., microorganisms intermediary to Actinomyces and Nocardia. Appl Microbiol 18, 340-349.

Groth, I., Schumann, P., Weiss, N., Martin, K. \& Rainey, F. A. (1996). Agrococcus jenensis gen. nov., sp. nov., a new genus of actinomycetes with diaminobutyric acid in the cell wall. Int J Syst Bacteriol 46, 234-239.

Han, S. K., Nedashkovskaya, O. I., Mikhailov, V. V., Kim, S. B. \& Bae, K. S. (2003). Salinibacterium amurskyense gen. nov., sp. nov., a novel genus of the family Microbacteriaceae from the marine environment. Int J Syst Evol Microbiol 53, 2061-2066.

Kämpfer, P., Rainey, F. A., Andersson, M. A. Q., Nurmiaho Lassila, E.-L., Ulrych, U., Busse, H. J., Weiss, N., Mikkola, R. \& SalkinojaSalonen, M. (2000). Frigoribacterium faeni gen. nov., sp. nov., a novel psychrophilic genus of the family Microbacteriaceae. Int J Syst Evol Microbiol 50, 355-363.

Kawamoto, I., Oka, T. \& Nara, T. (1981). Cell wall composition of Micromonospora olivoasterospora, Micromonospora sagamiensis, and related organisms. J Bacteriol 146, 527-534.

Kimura, M. (1980). A simple method for estimating evolutionary rates of base substitutions through comparative studies of nucleotide sequences. J Mol Evol 16, 111-120.

Lee, S. D. (2007). Labedella gwakjiensis gen. nov., sp. nov., a novel actinomycete of the family Microbacteriaceae. Int J Syst Evol Microbiol 57, 2498-2502.

Lin, Y.-C., Uemori, K., de Briel, D. A., Arunpairojana, V. \& Yokota, A. (2004). Zimmermannella helvola gen. nov., sp. nov., Zimmermannella alba sp. nov., Zimmermannella bifida sp. nov., Zimmermannella faecalis sp. nov. and Leucobacter albus sp. nov., novel members of the family Microbacteriaceae. Int J Syst Evol Microbiol 54, 1669-1676.

Manaia, C. M., Nogales, B., Weiss, N. \& Nunes, O. C. (2004). Gulosibacter molinativorax gen. nov., sp. nov., a molinate-degrading bacterium, and classification of 'Brevibacterium helvolum' DSM 20419 as Pseudoclavibacter helvolus gen. nov., sp. nov. Int J Syst Evol Microbiol 54, 783-789.

Männistö, M. K., Schumann, P., Rainey, F. A., Kämpfer, P., Tsitko, I., Tiirola, M. A. \& Salkinoja-Salonen, M. S. (2000). Subtercola boreus gen. nov., sp. nov. and Subtercola frigoramans sp. nov., two new psychrophilic actinobacteria isolated from boreal groundwater. Int $J$ Syst Evol Microbiol 50, 1731-1739.

Minnikin, D. E., Patel, P. V., Alshamaony, L. \& Goodfellow, M. (1977). Polar lipid composition in the classification of Nocardia and related bacteria. Int J Syst Bacteriol 27, 104-117.

Park, Y.-H., Suzuki, K., Yim, D.-G., Lee, K. C., Kim, E., Yoon, J., Kim, S., Kho, Y. H., Goodfellow, M. \& Komagata, K. (1993). Suprageneric classification of peptidoglycan group B actinomycetes by nucleotide sequencing of $5 \mathrm{~S}$ ribosomal RNA. Antonie van Leeuwenhoek 64, 307-313. 
Saito, H. \& Miura, K. (1963). Preparation of transforming deoxyribonucleic acid by phenol treatment. Biochim Biophys Acta 72, 619-629.

Saitou, N. \& Nei, M. (1987). The neighbor-joining method: a new method for reconstructing phylogenetic trees. Mol Biol Evol 4, 406-425.

Sasaki, J., Chijimatsu, M. \& Suzuki, K. (1998). Taxonomic significance of 2,4-diaminobutyric acid isomers in the cell wall peptidoglycan of actinomycetes and reclassification of Clavibacter toxicus as Rathayibacter toxicus comb. nov. Int J Syst Bacteriol 48, 403-410.

Schumann, P., Behrendt, U., Ulrich, A \& Suzuki, K. (2003). Reclassification of Subtercola pratensis Behrendt et al. 2002 as Agreia pratensis comb. nov. Int J Syst Evol Microbiol 53, 2041-2044.

Sheridan, P. P., Loveland-Curtze, J., Miteva, V. I. \& Brenchley, J. E. (2003). Rhodoglobus vestalii gen. nov., sp. nov., a novel psychrophilic organism isolated from an Antarctic Dry Valley lake. Int J Syst Evol Microbiol 53, 985-994.

Stackebrandt, E., Rainey, F. A. \& Ward-Rainey, N. L. (1997). Proposal for a new hierarchic classification system, Actinobacteria classis nov. Int J Syst Bacteriol 47, 479-491.

Suzuki, K., Sasaki, J., Uramoto, M., Nakase, T. \& Komagata, K. (1997). Cryobacterium psychrophilum gen. nov., sp. nov., nom. rev., comb. nov., an obligately psychrophilic actinomycete to accommodate "Curtobacterium psychrophilum" Inoue and Komagata 1976. Int J Syst Bacteriol 47, 474-478.

Suzuki, K., Suzuki, M., Uramoto, M., Sasaki, J., Park, Y.-H. \& Komagata, K. (1999). Leifsonia gen. nov., a genus for 2,4diaminobutyric acid-containing actinomycetes to accommodate "Corynebacterium aquaticum" Leifson 1962 and Clavibacter xyli subsp. cynodontis Davis et al. 1984. J Gen Appl Microbiol 45, 253-262.

Takahashi, Y., Matsumoto, A., Seino, A., Ueno, J., Iwai, Y. \& Ōmura, S. (2002). Streptomyces avermectinius sp. nov., an avermectinproducing strain. Int J Syst Evol Microbiol 52, 2163-2168.

Takeuchi, M. \& Hatano, K. (1998). Union of the genera Microbacterium Orla-Jensen and Aureobacterium Collins et al. in a redefined genus Microbacterium. Int J Syst Bacteriol 48, 739-747.

Takeuchi, M., Weiss, N., Schumann, P. \& Yokota, A. (1996). Leucobacter komagatae gen. nov., sp. nov., a new aerobic grampositive, nonsporulating rod with 2,4-diaminobutyric acid in the cell wall. Int J Syst Bacteriol 46, 967-971.

Tamaoka, J. \& Komagata, K. (1984). Determination of DNA base composition by reversed-phase high-performance liquid chromatography. FEMS Microbiol Lett 25, 125-128.

Tamaoka, J., Katayama-Fujimura, Y. \& Kuraishi, H. (1983). Analysis of bacterial menaquinone mixtures by high performance liquid chromatography. J Appl Bacteriol 54, 31-36.
Thompson, J. D., Higgins, D. G. \& Gibson, T. J. (1994). Clustal W: improving the sensitivity of progressive multiple sequence alignment through sequence weighting, position-specific gap penalties and weight matrix choice. Nucleic Acids Res 22, 4673-4680.

Tiago, I., Pires, C., Mendes, V., Morais, P. V., da Costa, M. \& Verissimo, A. (2005). Microcella putealis gen. nov., sp. nov., a Grampositive alkaliphilic bacterium isolated from a nonsaline alkaline groundwater. Syst Appl Microbiol 28, 479-487.

Tomiyasu, I. (1982). Mycolic acid composition and thermally adaptative changes in Nocardia asteroides. J Bacteriol 151, 828-837.

Tsukamoto, T., Takeuchi, M., Shida, O., Murata, H. \& Shirata, A. (2001). Proposal of Mycetocola gen. nov. in the family Microbacteriaceae and three new species, Mycetocola saprophilus sp. nov., Mycetocola tolaasinivorans sp. nov. and Mycetocola lacteus sp. nov., isolated from cultivated mushroom, Pleurotus ostreatus. Int $J$ Syst Evol Microbiol 51, 937-944.

Uchida, K. \& Aida, K. (1977). Acyl type of bacterial cell wall: its simple identification by a colorimetric method. J Gen Appl Microbiol 23, 249-260.

Wieser, M., Schumann, P., Martin, K., Alterburger, P., Burghardt, J., Lubitz, W. \& Busse, H.-J. (1999). Agrococcus citreus sp. nov., isolated from a medieval wall painting of the chapel of Castle Herberstein (Austria). Int J Syst Bacteriol 49, 1165-1170.

Yamada, K. \& Komagata, K. (1972). Taxonomic studies on coryneform bacteria. IV. Morphological, cultural, biochemical and physiological characteristics. J Gen Appl Microbiol 18, 399-416.

Yoon, J.-H., Kang, S.-J., Schumann, P. \& Oh, T.-K. (2006). Yonghaparkia alkaliphila gen. nov., sp. nov., a novel member of the family Microbacteriaceae isolated from an alkaline soil. Int J Syst Evol Microbiol 56, 2415-2420.

Yu, L., Takahashi, Y., Matsumoto, A., Seino, A., Iwai, Y. \& Omura, S. (2002). Application of PCR for selection of Gram-positive bacteria with high DNA G $+\mathrm{C}$ content among new isolates. Actinomycetologica 16, 1-5.

Zgurskaya, H. I., Evtushenko, L. I., Akimov, N., Voyevoda, H. V., Dobrovolskaya, T. G., Lysak, L. V. \& Kalakoutskii, L. V. (1992). Emended description of the genus Agromyces and description of Agromyces cerinus subsp. cerinus sp. nov., subsp. nov., Agromyces cerinus subsp. nitratus sp. nov., subsp. nov., Agromyces fucosus subsp. fucosus sp. nov., subsp. nov., and Agromyces fucosus subsp. hippuratus sp. nov., subsp. nov. Int J Syst Bacteriol 42, 635-641.

Zgurskaya, H. I., Evtushenko, L. I., Akimov, N. \& Kalakoutskii, L. V. (1993). Rathayibacter gen. nov., including the species Rathayibacter rathayi comb. nov., Rathayibacter tritici comb. nov., Rathayibacter iranicus comb. nov., and six strains from annual grasses. Int J Syst Bacteriol 43, 143-149. 